\title{
Laboratory handling and rearing of early instar porina larvae from eggs
}

\author{
S.R. Atijegbe ${ }^{1}$, S. Mansfield ${ }^{2}$, M. Rostas ${ }^{1}$, C.M. Ferguson ${ }^{3}$ and S. Worner ${ }^{1}$ \\ ${ }^{1}$ Bio-Protection Research Centre, Lincoln University, PO Box 85084, Christchurch 7647, \\ New Zealand \\ ${ }^{2}$ AgResearch Ltd, Lincoln Research Centre, Private Bag 4749, Christchurch 8140, New Zealand \\ ${ }^{3}$ AgResearch Ltd, Invermay Agricultural Centre, Private Bag 50034, Mosgiel 9053, New Zealand \\ Corresponding author: sylvesterrichard.atijegbe@lincolnuni.ac.nz
}

\begin{abstract}
Mass rearing Wiseana (porina) species, a major endemic insect pest in New Zealand pastures, has proved challenging for research and pest management and has presented problems over several decades in the laboratory. Researchers have acknowledged that handling the eggs and first instar larvae are of critical importance during laboratory rearing. A simple method is presented that improves survival of early instar porina larvae. Eggs of three porina species (W. cervinata, W. copularis, W. umbraculata) hatched faster at $22^{\circ} \mathrm{C}$ than at $15^{\circ} \mathrm{C}$.
\end{abstract}

Keywords Wiseana, rearing methods, temperature, development time.

\section{INTRODUCTION}

Wiseana Viette (Lepidoptera: Hepialidae), also known as porina, is a complex of seven New Zealand endemic species. They are major insect pests of pastures that are critical for livestock production in New Zealand. With the recent reclassification of this species complex (Dugdale 1994), it is essential to correctly identify species in pasture in different parts of New Zealand and to be able to rear them for research purposes. The greatest challenge in conducting research with porina is the difficulty in laboratory rearing because of their long life cycle of 12-14 months. Allan et al. (2002) reported that porina larvae could be difficult to rear in the laboratory for research purposes from eggs. As a result, very little is known about the fundamental biology of porina, their native habitat(s) and what porina feed on in these habitats. In pastures, porina eggs and first instar larvae are very susceptible to desiccation (Stewart 2001), and dry summers during the egg and early instar stages usually result in small porina numbers the following winter (unpublished data). Newly hatched porina larvae are much more susceptible to desiccation than eggs, and the susceptibility of Wiseana spp. larvae to desiccation decrease with age (Stewart 2001). The most drought-susceptible stage in porina's life cycle is the egg during hatching, and hatching does not occur at $0 \%$ relative humidity (RH) (Stewart 2001). The rate of development of porina eggs is significantly affected by temperature (French \& Pearson 1979), as is the case for all insects. Although porina lay a large number of eggs, mortality of early instar larvae is very high (Barratt et al. 1990), and even in late instars can be as high as $90 \%$ (Moore 
1972; Fleming et al. 1986). In the laboratory, current challenges in rearing porina include larvae drowning after hatching in the container, contamination from disease-causing organisms on the egg surfaces, diseases from viruses transmitted from the mother to her offspring, competition/cannibalism of larvae in rearing containers, the composition of the medium that larvae are transferred onto after hatching for rearing and the type of diet fed to larvae during rearing. The rearing from eggs to adults in the laboratory provides opportunities to study the physiology of the immature life stages and how to manage them. It also makes species identification of larvae using DNA easier and cheaper because only the parent needs to be identified, compared to field collected larvae where every individual needs to be DNA tested.

Various studies have previously attempted to rear hepialid larvae in the laboratory, but with limited success. Waller (1968) unsuccessfully tried to rear porina larvae in peat-filled cans but achieved some success of rearing larvae to first instar in agar-filled dishes. Elder (1970) reared the hepialids Oncopera brachyphylla and $O$. mitocera in a multi-temperature incubator ranging from $10-27^{\circ} \mathrm{C}$, and found that the optimal rearing temperature was dependent on species. The most successful method reported to date was that of Wood (1970), which reared porina larvae in 5-inch plastic flower pots nearly filled with a mixture of two parts of sterilised earth, one part of old pine sawdust to which 1 to 16 parts of fine sand was added. They were fed wilted clover, and $37 \%$ of larvae emerged as adults. Dodgshun (1970) studied viral diseases of Wiseana spp. and found that use of an artificial maintenance medium saved much time when feeding larvae and adapted the semi-synthetic maintenance diet first employed by Shorey \& Hale (1965) to raise noctuid larvae. French \& Thomas (1971) reared field-collected larvae on agar for 100 days by feeding them with clover leaves. French \& Pearson (1979) studied the effect of temperature at $100 \%$ relative humidity $(\mathrm{RH})$ on the rate of porina egg development under different constant temperature regimes and found that the number of days required for hatching increased with decreasing temperature. Wagner (1989) used carrot to rear larvae of the hepialid moths Hepialus humuli, $H$. californicus, $H$. behrensii, $H$. hectotoides, Phassus triangularis and Korscheltellus gracilis to adults. Carpenter (1983) showed that copper oxychloride enhanced the viability of porina eggs in laboratory cultures. It overcame mould problems associated with laboratory cultures of porina eggs, and is cheap and easily obtained. Stewart (2001) reported that newly hatched larvae of the pasture pest Wiseana copularis were much more susceptible to desiccation than eggs, except for those in the process of hatching. There was no successful hatching at $0 \%$ RH. Ferguson \& Crook (2004) reported that egg hatch time decreases with an increase in temperature from $10-20^{\circ} \mathrm{C}$ for $W$. cervinata and W. copularis. Popay (2001) reported a mass-rearing technique for porina adults from eggs using a diet with seven ingredients including clover and carrot that was modified from the semi-synthetic diet of Dodgshun (1970) but no data on survival rate were provided. Using this method, larvae were reared through to adults in about 8 months. Ferguson \& Crook (2004) successfully reared larvae hatched from eggs collected from adults that emerged from field populations. The larvae were reared individually at $10,13,16$, and $20^{\circ} \mathrm{C}$ in Petri dishes containing moistened bark and fed a semi-synthetic diet based on white clover and carrot with $61 \%$ W. cervinata and $68 \%$ $W$. copularis larvae pupating successfully at $16^{\circ} \mathrm{C}$. Similar success was also achieved when the artificial diet was substituted with white clover without formaldehyde at the second or later larval instars and with a commercial potting mix (Yates Thrive) instead of bark (Ferguson unpublished). The method currently used by researchers for rearing porina is based on the methods of Popay (2001) and Ferguson \& Crook (2004). It involves sterilisation by washing eggs in a solution of 1 $\mathrm{mg} /$ litre of copper sulphate, rinsing them with distilled water and then transferring them to damp filter paper in Petri dishes and keeping them at $20^{\circ} \mathrm{C}$ to hatch. 
This study presents some improvements to current rearing methods that are particularly useful for experimental studies of host-plant responses in porina.

\section{MATERIALS AND METHODS}

\section{Egg collection and surface sterilisation}

Adult female porina moths were hand collected between 21:00 $\mathrm{h}$ and 01:30 $\mathrm{h}$ from a light trap located at the AgResearch farm (43⒊'10.6"S $\left.172^{\circ} 28^{\prime} 19.5^{\prime \prime E}\right)$ on Springs Road, Lincoln. Individual females were put into numbered 120$\mathrm{mL}$ plastic bottles so that the larvae from each female could be matched back to their parent after each adult was identified to species using the DNA method of Richards et al. (in press). Moths were placed at room temperature close to a light source for about 4 hours, and they were excited by shaking the container once or twice to make them lay their eggs within 1-2 days.

Filter papers $(90 \mathrm{~mm})$ were immersed in a solution of $1 \mathrm{mg} /$ litre of copper sulphate for 2 minutes and were drained on paper towels to remove excess solution. Moist filters papers were placed at the bottom of Petri dishes (90$\mathrm{mm}$ diameter) and 50 eggs/Petri dish from each female was spread thinly over the papers to sterilise the eggs. The Petri dishes $(n=30)$ were covered with their lids and sealed on the side with Parafilm ${ }^{\circledR}$ to retain moisture and to prevent larvae from escaping. Ten Petri dishes per species were prepared, containing eggs of $W$. copularis, $W$. cervinata and $W$. umbraculata, respectively. Petri dishes for each species were split into two batches; one batch was kept in a constant temperature (CT) cabinet (CAT.190 RHS, Contherm Scientific Ltd) at $15^{\circ} \mathrm{C}$ and remaining Petri dishes were stored in a second CT cabinet at $22^{\circ} \mathrm{C}$. The photoperiod in both cabinets was with 12L:12D. The eggs were observed daily until eggs started to hatch and the date recorded.

\section{Rearing medium and larval diet}

Once larvae started hatching, all 50 eggs/ larvae from each Petri dish were transferred immediately into a 3 L Sistema ${ }^{\circledR}$ plastic container (230 mm x $175 \mathrm{~mm} \times 120 \mathrm{~mm}$ ) half filled with
Grade-2 moist horticultural bark (HB) sourced from Intelligro (formerly known as Southern Horticultural Products). There was a separate container for all the larvae from each Petri dish. The larvae were fed weekly with carrot (Daucus carota) pieces for 8 weeks. The epidermal layer was scraped off the carrot and it was dipped in hot water for one minute to remove any residual pesticides then chopped with a knife into pieces about 50-100 mm thick.

\section{Statistical analysis}

One-way ANOVA was used to compare hatching times between porina species at each temperature. Post-hoc comparison using Student-NewmanKeuls (SNK) was done to separate means.

\section{RESULTS AND DISCUSSION}

Early attempts at rearing the eggs using the washing technique described by Popay (2001) often resulted in drowning of newly hatched larvae (up to $90 \%$ mortality) due to excess moisture (data not shown). The modified sterilisation technique described here reduced moisture levels so that larval survival improved substantially (Table 1). Both soil and vermiculite were tested initially but these needed to be moistened once or twice a week to avoid desiccation of larvae whereas Grade- 2 moist bark retained moisture better and needed changing only once per month.

The semi-synthetic diet used by Popay (2001) is an effective food source for porina but the recipe includes clover as an essential ingredient, which was one of the target hosts for the planned hostplant preference and performance experiments. Removing the clover from this semi-synthetic diet led to high larval mortality (data not shown) so an alternative was required. Carrot was cheap, readily available and removed any risk of preconditioning the porina larvae.

Ferguson \& Crook (2004) reported that egg hatch time decreased with an increase in temperature from $10-20^{\circ} \mathrm{C}$ for W. cervinata and $W$. copularis. The results of the current study supported these earlier findings since eggs of all species hatched more quickly at the higher of the 
two temperatures examined $\left(22^{\circ} \mathrm{C}\right.$ compared with $15^{\circ} \mathrm{C}$, Table 1 ). Also, W. cervinata eggs hatched faster than the other two species at both temperatures $\left(15^{\circ} \mathrm{C}: \mathrm{F}_{2,12}=4.39, \mathrm{P}=0.018 ; 22^{\circ} \mathrm{C}\right.$ : $\left.\mathrm{F}_{2,12}=26.92, \mathrm{P}<0.001\right)$ whereas $W$. copularis was slowest. Ferguson and Crook (2004) also found that $W$. cervinata eggs hatched earlier than $W$. copularis eggs when reared at $10,13,16$ and $20^{\circ} \mathrm{C}$, with $W$. cervinata and W. copularis eggs hatching in 15 and 18 days respectively at $20^{\circ} \mathrm{C}$. Importantly, the current study presents the first data on development of $W$. umbraculata. Larval survival was high $\left(15^{\circ} \mathrm{C}: 47,45,46\right.$ and $22^{\circ} \mathrm{C}$ : $45,46,46$ for $W$. cervinata, W. copularis and W. umbraculata respectively, with no significant difference in larval survival $\left(15^{\circ} \mathrm{C}: \mathrm{F}_{2,12}=2.50\right.$, $\left.\mathrm{P}=0.124 ; 22^{\circ} \mathrm{C}: \mathrm{F}_{2,12}=0.769, \mathrm{P}=0.485\right)$ at either temperature (Table 1 ).

Ferguson \& Crook (2004) reared larvae individually, which is considerably more time consuming than the mass-rearing approach of 50 larvae per container used here. Also, they reported larval survival rates at pupation of $61-68 \%$ whereas the survival rate at 8 weeks in the current study was $\geq 90 \%$. The rearing method presented here is also cheaper (as it did not require the purchase of specialised chemicals) and simpler (as it did not involve multiple ingredients and takes much less time to prepare) than previous methods. Also, the higher temperature $\left(22^{\circ} \mathrm{C}\right)$ used here resulted in faster hatching of eggs compared with earlier studies $\left(10-20^{\circ} \mathrm{C}\right)$. This method has the added advantages that carrot is always available and it does not pre-condition larvae to a common pasture species (clover), which is important for experiments focused on host plant interactions in porina.

\section{ACKNOWLEDGMENTS}

We thank Richard Townsend for providing the light trap and Rob Phiskie for hosting the trap on the AgResearch farm. We also thank the New Zealand Aid Programme (NZ Aid), Hellaby Trust, Macmillan Brown Agricultural Scholarship, University of Port Harcourt, Nigeria and New Zealand Plant Protection Society (NZPPS) for supporting the lead author's research.

\section{REFERENCES}

Allan RA, Wang Q, Jiménez-Pérez A, Davis, LK 2002. Wiseana copularis larvae (Hepialidae: Lepidoptera): Laboratory rearing procedures and effect of temperature on survival. New Zealand Journal of Agricultural Research. 45(1): 71-75, DOI:10.1080/00288233.2002.9 513495.

Barratt BIP, van Toor RF, Ferguson CM, Stewart KM 1990. Grass grub and porina in Otago and Southland. A guide to management and control. MAF Technology, Dunedin, New Zealand.104 p.

Carpenter A 1983. Chemical treatment of porina eggs to prevent loss of viability in culture. New Zealand Entomologist 7(4): 466-467.

Dodgshun TJ 1970.A semi-synthetic maintenance diet suitable for hepialid and melolonthid larvae. New Zealand Entomologist 4:4.

Dugdale, JS 1994. Fauna of New Zealand. Number 30: Hepialidae (Insecta: Lepidoptera). Manaaki Whenua Press, Lincoln, Canterbury, New Zealand. 164p.

Elder RJ 1970. A rearing technique for Oncopera brachyphylla Turner and Oncopera mitocera (Turner). Queensland Journal of Agricultural and Animal Sciences 27: 401-404.

Table 1 Hatch time (mean \pm sd) for eggs and survival (mean \pm sd) at 8 weeks for larvae of three porina species (Wiseana spp.) at two rearing temperatures. Means in the same column followed by the same letter are not significantly different $(\mathrm{P}>0.05)$.

\begin{tabular}{llllclc}
\hline Porina species & & & $15^{\circ} \mathrm{C}$ & & $22^{\circ} \mathrm{C}$ \\
& Hatch time & $\mathrm{N}$ & Survival & Hatch time & $\mathrm{N}$ & Survival \\
\hline W. cervinata & $16 \pm 1.7 \mathrm{a}$ & 50 & $47 \pm 1.0 \mathrm{a}$ & $9 \pm 1.6 \mathrm{a}$ & 50 & $45 \pm 1.9 \mathrm{a}$ \\
W. copularis & $32 \pm 15.0 \mathrm{~b}$ & 50 & $45 \pm 1.6 \mathrm{a}$ & $17 \pm 1.9 \mathrm{~b}$ & 50 & $46 \pm 1.6 \mathrm{a}$ \\
W. umbraculata & $28 \pm 1.8 \mathrm{~b}$ & 50 & $46 \pm 1.6 \mathrm{a}$ & $14 \pm 1.6 \mathrm{c}$ & 50 & $46 \pm 0.7 \mathrm{a}$ \\
\hline
\end{tabular}


Ferguson CM, Crook KE 2004. The development of two Wiseana species and the implications for their management as pastoral pests. In: Winder LM, Goldson SL eds. Proceedings of the 8th Australasian Conference on Grassland Invertebrate Ecology Pp. 87-93.

Fleming SB, Kalmaskoff J, Archibald RD, Stewart KM 1986. Density-dependent virus mortality in populations of Wiseana (Lepidoptera: Hepialidae). Journal of Invertebrate Pathology 48: 193-198.

French RA, Pearson JF 1979. Influence of temperature on the rate of development of porina (Wiseana spp.: Hepialidae) eggs and timing of larval emergence in the field. New Zealand Journal of Experimental Agriculture 7: 315-319.

French RA, Thomas GW 1971.A method of rearing caterpillars of porina (Wiseana sp.) in the laboratory. New Zealand Entomologist 5:3539 DOI: 10.1080/03015521.1979.10429092.

Moore SG 1972. A virus outbreak kills porina. New Zealand Journal of Agricultural Research 124: 39-41.

Popay AJ 2001. A laboratory rearing method for porina [poster]. New Zealand Plant Protection 54: 251.
Richards NK, Mansfield S, Townsend RJ, Ferguson CM 2017. Genetic variation within species and haplotypes of the Wiseana (Lepidoptera: Hepialidae) complex and development of non-sequenced based identification tools to aid field studies. Pest Management Science. In press. doi:10.1002/ps.4620

Shorey HH, Hale RL 1965. Mass rearing of the larvae of nine Noctuid species on a simple artificial medium. Journal of Economic Entomology 58: 522-524.

Stewart KM 2001. Relative susceptibility to desiccation of eggs and young larvae of the pasture pest Wiseana copularis (Lepidoptera: Hepialidae). New Zealand Journal of Agricultural Research 44: 177-180, doi: 10.1080/00288233.2001.9513475.

Wagner DL 1989. Rearing hepialid moths (Lepidoptera). Pan-Pacific Entomologist 65: 391-396.

Waller JB 1968. Handling techniques for eggs and larvae of Wiseana sp. (Hepialidae). New Zealand Entomologist 4(1): 57-60.

Wood J 1970. Rearing Wiseana species in the laboratory. New Zealand Entomologist 4(4): 3-7. 